\title{
OBITUARIES
}

\section{Prof. J. B. S. Haldane, F.R.S.}

John Burdon Sanderson Hatdane died in India on December 1, 1964, at the age of seventy-two. Educated at Eton and New College, Oxford, where he obtained firstclass honours in mathematics and Greats, he served during the First World War in the Black Watch, returning to Oxford after the War to a fellowship of New College. In 1922 he joined the Department of Biochemistry in the University at Cambridge, where he later became a reader. In 1927 he moved to become head of the Department of Genetics in the John Innes Horticultural Institution, and in 1930 to become Fullerian professor of physiology in the Royal Institution. In 1933 he moved to University College, London, where he was to stay until his retirement in 1957, first as professor of genetics and then, from 1937 onwards, as professor of biometry. On his retirement he moved to India, becoming a citizen of that country in 1960; he worked first at the Indian Statistical Institute, and finally as director of the Genetics and Biometry Laboratory in Bhubaneswar.

From his boyhood he had taken part, both as experimental subject and scientific collaborator, in the researches of his father, Prof. J. S. Haldane, on the physiology of human respiration. While at Cambridge, he continued to organize teamwork on human physiological and biochemical processes, with himself as the chief experimental animal. Still remembered with awe by those who took part were the prolonged investigations of acidosis following massive doses of ammonium chloride and other salts, during which the subject becomes "less equable".

Haldane's biochemical work was mainly theoretical. The most notable were his contributions, with Briggs, to enzyme kinetics and his monograph on Enzymes published in 1930. In his garden on the outskirts of Cambridge he and Miss Winton carried out elaborate genetic studies on Primula sinensis, which supplied data for his mathematical work on the measurement of genetic linkage. At Cambridge also he made a brilliant start in 1924 as a popularizer of science with his book Daedalus, or Science and the Future.

In a series of papers starting in 1924 Haldane worked out the consequences of Mendelian genetics for the theory of evolution. The conclusions which emerged from these investigations included estimates of the rates of change of the frequency of dominant and recessive genes under various types of selection; the possibility of stable equilibria with intermediate gene frequencies when the heterozygote is the fittest of the three genotypes; the effects of selection on a character influenced by many genes; the relative importance of selection and mutation in determining the rate and direction of evolution; and the possibility of estimating spontaneous mutation rates from observations of the frequencies of harmful dominant or sex-linked genes in natural populations. This last conclusion led him to an estimate of the mutation rate at the haemophilia locus, and so to the first estimate of a human mutation rate. During the same period, between 1924 and 1932, Sewall Wright and R. A. Fisher were carrying out, largely independently, investigations into the same general problems; between them, these three men became the architects of the mathematical theory of population genetics. Haldane continued to publish papers in this field throughout his life, and at the time of his death was working on the problem of 'selection with replacement', in which it is supposed that a female bears an additional child if one of her children dies young for genetic reasons. His paper on "The Cost of Natural Selection", published in 1957, was the starting point of the present widespread interest in the concept of 'genetic loads'.

While at University College, through his association with the Galton Laboratory, Haldane became increasingly interested in human genetics, and he continued this interest after moving to India, where he stimulated a number of young scientists to exploit the peculiar advantages of that country to a human geneticist. His own contributions were mainly mathematical. He developed methods of measuring linkage in human pedigrees, and, with Julia Bell, determined the first map distance in man, between haemophilia and colour blindness. He developed statistical techniques to allow for the bias in estimating segregation ratios in human pedigrees. Perhaps most important, he gave continual encouragement to the application of biochemical methods in human genetics. His book Heredity and Politics, published in 1938, is probably still the most balanced discussion of what measures are and are not likely to be effective or desirable in the field of eugenies.

His influence on the development of human genetics is typical of his influence on the development of biology as a whole. He had two convictions which persisted throughout his scientific career, and which, together with his formidable intelligence, determined his scientific behaviour. The first was that, if you are faced by a difficulty or a controversy in science, an ounce of algebra is worth a ton of verbal argument. This attitude was displayed, for example, in his calculations on the relative importance of selection and mutation, or in his demonstration of the comparative ineffectiveness of the steriliza. tion of the unfit on eugenic grounds. Such an outlook has been characteristic of physics since the time of Newton; if it is to-day becoming characteristic of biology, this is to a significant extent due to Haldane's influence. $\mathrm{He}$ did not confine this attitude to science; his book A.R.P., published during the Munich crisis in 1938, was one of the first, and most successful, attempts to treat an essentially military problem quantitatively. If Haldane could write dispassionately about subjects which arouse strong emotions, it was not because he was a man without feelings, but because he had learnt to discipline his passions with mathematics. In politics, as he would probably have admitted himself, his judgment was less reliable, perhaps because political problems are not as yet readily amenable to mathematical treatment.

Haldane's second continuing conviction was that a physiological or biochemical explanation is more fundamental than a morphological one. From the first he was convinced that genetics must receive a biochemical interpretation. He himself lacked the technical skills and the facilities to do for biochemical genetics what he had done for mathematical genetics. But through his books and lectures, and through personal contact, he gave the impetus to many of those who have turned his conviction into a reality.

Haldane contributed to many branches of science outside biochemistry and genetics, from cosmology to animal behaviour and from telepathy to the physiology of diving. He was also perhaps the most gifted popularizer of science of his time. This last gift may seem unexpected in one whose papers were full of algebra, but in fact the gift for popularization was merely another aspect of his gift for turning biology into mathematics. Haldane was by no means a great mathematician, although he was a very energetic and courageous one, but he did have a genius for taking a complex biological problem and simplifying it to the stage at which it could be posed in mathematical form, without at the same time distorting 
it out of recognition. It was this samo gift for simplifying without distortion which he used in his essays, and in his weekly articlos in the Daily Worker.

In The Causes of E'volution, Haldine wrote: "Intonso selection favours a variablo rosponse to the environment. ... Were this not so, the world would be much duller than is actually the case". For his friends and colleaguos, the world has been a dullor place since last December. John Maynard Smith

\section{Mr. R. E. Garrod}

RALPH EDDowes Garrod, who died on September 25, 1964, was the second son of H. B. Garrod, barrister-at-law of Hampstead, and grandson of Sir Alfred Garrod. He was born on March 29, 1889, and was educated at Oundlo and at Clare College, Cambridge. A schoolboy contemporary at Oundle was E. K. Rideal (later Sir Eric Rideal, professor of colloid science, Cambridge). At Cambridge Garrod was a running Blue, and it is of interest to recall that one of his duties in this capacity was to award colours to A. W. Tedder (now Marshal of the Royal Air Forco, Lord Tedder). After taking a doublo first in science, he carried out chemical research on aldol bases under the direction of $H$. $O$. Jones. The work was described in two papers contributed to the Transactions of the Chemical Society $(101,1376,1389 ; 1912)$.

Garrod then entered industry as a chemist in the fur dressing and dyeing factory of Messrs. C. W. Martin and Sons, Ltd., London, the leading company in this business whose activities dated from 1823. With the chief chemist, J. P. Millington (a formor scholar of Christ's College, Cambridgo), ho carried out investigations on the application of the oxidation type of dyestuff recently introduced by Erdmann in Germany. Theso dyostuffs, based on $p$ phenylene diamine and aminophenols, were replacing the mordant-wood colours which had been used from the Middle Ages. Millington and Garrod must havo been two of the earliest chemists to enter this craft industry whose activities on the fur dressing side stretch back into the mists of pre-history.

During the First World War he combined work at Martins (largely concerned with processing of goat skins for the troops) with censorship duties at the War Office. In 1928 , "R. E. G.", as he was known to his colleagues, took over sole responsibility for tho tochnical side of factory operations and was to continue in charge, as chief chemist and lator as technical director, until his retirement in 1955 .
His work carried the unmistakable imprint of a keen intellect finely disciplined by scientific method. His personal integrity, his wide knowledge of men and affairs, and his shrewd judgments won him the respoct and affection of all his associates. Ho played an outstanding role in tho tcchnical successes of his firm, and his influeneo is still to be felt in the standards he set which continue to guide his successors.

Although ho rotirod as an executive director in 1955, at the request of his co-directors he remained a momber of the board and continued in this eapacity until his death. He was a member of numerous scientific and technical socie. ties. For many years he was a member of the London Section Committee of the Socioty of Dyers and Colourists, and also servod on the Publications Committee of the Society.

He was a very modost man, and many of his nonprofessional colloaguos and associates were unaware that ho represented the third generation of outstanding sciontific ability in his family. His grandfather, Sir Alfred Garrod, was a distinguished clinician and pioneer in the application of chemistry to medicine. It was he who first demonstrated the increased concentration of uric acid in the blood of patients with gout. His uncle, Sir Archibald Garrod, a physician at St. Bartholomew's Hospital and later Regius professor of physics, University of Oxford, was the undoubted pionoer of human biochemical genetics. In his famous work, Inborn Errors of Metabolism, published early in the century, he developed a series of now concepts about the character of inhorited deviations in human biochemistry which are now accepted as part of everyday thought on these matters. His younger brother, whom he predeceased by only a fow months, was Air Chief Marshal Sir Guy Garrod.

Ralph Garrod possessed in fine measure the enquiring and analytical mind which characterizod the earlier scientific members of his family. He not only applied it in his professional capacity, but also after his retirement it found scope in his interest in local governmont affairs. $\mathrm{H}_{\Theta}$ took up rosidence in Winchelsea, became a Freeman and Jurat of this Cinque Port, and at the time of his death occupied the office of Mayor. At his memorial service high tribute was paid to the invaluable service he had rendered on committees and in his work for the town.

Ho is survived by his widow, and by the six children of his first marriage. The family scientific and medical tradition is continued by his elder son, who is a consultant physician.

J. L. Stoves

\section{NEWS and VIEWS}

\section{Chief Scientific Officer in the Cabinet Office:}

Mr. F. H. Allen

Mr. F. H. $\Lambda_{\text {LLAN, }}$ until recently director of the Hydraulics Research Station of the Departrnent of Scientific and Industrial Research, has bon appointed Chicf Scicntific Officer in the Cabinet Office. He will act as principal assistant to Sir Zolly Zuckerman, whoso appointment as Scientific Adviser to the Cabinet Office, in addition to his duties as Chief Scientific Adviser in the Ministry of Defence, was announced in October 1964. Mr. Allen graduated with first-class honours in ongineoring from Trinity College, Dublin, in 1943 and then joined a consortium of consulting engineers in London engaged on the construction of units of Mulberry Harbour for the invasion of Normandy. After tho Second World War he was assistant engineer to a firm of civil engineering consultants, Sir Cyril Kirkpatrick and Partners; and early in 1949 ho was appointed by the Port of London Authority to take charge of research into siltation in the
Thames estuary-under the general supervision of the newly-formod Hydraulics Research Organization of the Department of Scientific and Industrial Researeh. Mr. Allen joined the Hydraulics Research Station at Wallingford as assistant dircctor in 1952, and was concerned in particular with research into problems in tidal hydraulies. He was appointed director in 1958. As part of his duties, ho travollod extensively in connexion with overseas prob. lems in civil engineering hydraulics, and in 1961 he was elected vice-president of the International Association for Hydraulic Research. Mr. Allen is a member of Council of the Institution of Civil Engineers, and was awarded the Institution's 'Telford Gold Modal in 1957. He took up his new dutios in the Cabinet Office on January 18.

\section{University of Bristol :}

Prof. J. E. Harris, C.B.E., F.R.S.

Prof. J. E. Harris, professor of zoology in the University of Bristol, has been appointed Vice-Chancellor 